\title{
MENGAJAR DI TPA NURUL QALBY
}

\author{
NURANI
}

NIM: 9173770410369

Email: Nurani21093@gmail.com

\section{Bentuk Kegiatan}

Mengajar Mangaji Iqra dan Al-Qur'an Besar di TPA Nurul Qalby

\section{Lokasi}

Dusun Bontoa, Desa Balangloe tarowang, kec. Tarowang

\section{Hari/Tanggal dan Waktu}

Pada hari senin tgl 13 Oktober 2020

Pukul 18:10 wita

4.Peserta yang Dilibatkan -Ustadz Tpa Nurul Qalby -Peserta KKLP

-Santriawan / Wati

\section{Alasan Diadakannya} Agar anak-anak bisa lebih paham tentang huruf-huruf hijayyah dan lebih faham tentang arti dan makna

\section{Tujuan dan Manfaat}

- Tujuan Agar peserta didik menjadi generasi Qur'an yang mencintai Al-Qur'an dan menjadikan Al-Qur'an sebagai

Bacaan dan pandangan hidup sehari-hari

- Manfaat Menjadi bekal untuk menghadapi hari akhir,mendapatkan pahala yang berlipat ganda dan dikumpulkan bersama para malaikat.

\section{Produk Kegiatan (Jika} Ada)

-Buku Iqro,

-Al-Qur,an

\section{Deskripsi Kegiatan}

Adalah proses perubahan tingkah laku peserta didik melalui proses belajar mengajar,membimbing,da $n$ melatih peserta didik 
untuk membaca Al-Qur'an dengan fasi dan benar sesuai kaidah ilmu tajwid agar peserta didik terbiasa belajar membaca Al-

\section{Referensi Wajib}

- HERIANTO, H., \& Amir, A. S. (2020, September 10). Pedoman Pelaksanaan Kuliah Kerja Lapangan Plus (KKLP) Mahasiswa STIE dan STKIP YAPTI Jeneponto. https://doi.org/10.31219/osf.io/7dvpk 